\title{
ENDOCRINE DISRUPTORS: GENERAL CHARACTERISTICS, CHEMICAL NATURE AND MECHANISMS OF ACTION. A REVIEW.
}

\author{
Chmelíková Eva ${ }^{1}$, Sedmíková Markéta $^{1}$, Ješeta Michal ${ }^{2}$, Němeček David ${ }^{1}$
}

\begin{abstract}
Over recent decades, different types of industrially manufactured chemicals have become widespread environmental contaminants with potential to interfere with the synthesis, secretion, transport, binding or elimination of natural hormones in the body. These chemical substances were named endocrine disruptors (EDs). The main route of exposure to EDs is the ingestion of contaminated food and water. EDs are very dangerous, because they have long half-life, stay present in the environment for years and may concentrate at great distances from the site where were produced. The group of EDs is heterogeneous and contains industrial lubricants, solvents, plastics, plasticizers, pesticides, fungicides, drugs, but also natural chemicals. The mechanisms of EDs action are difficult to predict, many substances act by interfering with the estrogen receptors (ER), androgen receptor (AR), thyroid receptors (TRs) and aryl hydrocarbon receptor (AhR), but they can also influence hormone synthesis or can have effect on epigenetic mechanisms. Further research is necessary to improve knowledge about EDs and their metabolites, and to identify endocrine-disruptive potential of chemicals, those replacing current EDs before they are widely distributed.
\end{abstract}

Running title: Endocrine disruptive compounds and their effects

Keywords: endocrine disruptors, chemicals, mixture interaction, toxicity mechanism

\footnotetext{
${ }^{1}$ Department of Veterinary Sciences, Czech University of Life Sciences Prague, Faculty of Agrobiology, Food and Natural Resources, Kamýcká 129, 165 00, Czech Republic

${ }^{2}$ Department of Obstetrics and Gynecology, University Hospital and Masaryk University, Obilní trh 11, 60200 Brno, Czech Republic

* Correspondence: chmelikova@af.czu.cz

Full list of author information is available at the end of article
} 


\section{General characteristics of endocrine disruptors (EDs)}

Since the mid-20 $0^{\text {th }}$ century, different types of industrially manufactured pesticides, chemicals, plastics, detergents, paints and cosmetics have become widespread environmental contaminants with potential to disrupt the closed feedback loops of the hormonal and homeostatic systems and consequently cause adverse health effects in an intact organism, or its progeny. For this ability, they were named endocrine disruptors (EDs) [1, 2]. U.S. Environmental Protection Agency (EPA) defined an endocrine disruptor as an agent that interferes with the synthesis, secretion, transport, binding or elimination of natural hormones in the body that are responsible for the maintenance of homeostasis, reproduction, development and/or behaviour [3]. Exposure of human and animals to EDs may occur in a variety of ways. For majority of these chemicals, the main source of exposure is via food, drinking water, breathing contaminated air or contacting contaminated soil $[4,5,6]$.

Endocrine disruptors produce their effects by mimicking, antagonizing or altering endogenous steroid levels, via changing rates of their synthesis or metabolism or expression and action at receptor targets. The EDs have some characteristics that potentiate their hazards. Many of the EDs are lipophilic, so they have very low water solubility and accumulate in adipose tissue [7, 8]. Very dangerous are mixtures of the EDs, they can influence one another in an additive, adverse, or synergistic way. Several studies have shown that chemicals have no observed effect level (NOEL) individually, while when present simultaneously as a mixture they show adverse effect disproving the concept of NOEL and bring more attention toward mixture studies $[9,10]$. Most common is a non-linear dose response effect of the disruptor. Paradoxically, low concentrations can achieve greater effects than high doses $[11,12]$. Further, the EDs show disparate responses at different stages of life, dependent on physiological concentrations of hormones, challenging current risk assessment methodologies, which are not in consonance with life-stage changes $[13,14]$. Moreover, these metabolites are not taken into account when the parent compounds are administered as is done in the majority of in vitro experiments [15].

\section{Chemical nature of endocrine disruptors}

The group of known EDs is extremely heterogeneous. The EDs can be classified in two categories:

1) Those that are synthesized. These can be grouped as follows:

a) synthetic substances used as industrial lubricants and solvents, and their by-products: e.g. polychlorinated biphenyls (PCBs), polybrominated diphenyl ethers (PBDE) and dioxins e.g. 2,3,7,8-tetrachlorodibenzo-p-dioxin (TCDD), decabromodiphenylethane (DBPDE) b) plastics: bisphenols - e.g. bisphenol A (BPA) and bisphenol S (BPS)

c) plasticizers: e.g. phthalates

d) pesticides: e.g. atrazine, cypermethrin, dichlordiphenyltrichlorethane (DDT), dieldrin, methoxychlor (MTX) and its metabolites e.g. 2,2-bis(p-hydroxyphenyl)-1,1,1-trichloroethane (HPTE), endosulphan

e) fungicides: e.g. vinclozolin (VCZ), dicarboximid, hexachlorbenzene (HCB)

f) and drugs: e.g. diethylstilbestrol (DES) and ethinyloestradiol (EE) as well as non-steroidal anti-inflammatory drugs (NSAID) and acetaminophen

2) Those that occur naturally.

a) natural chemicals such as a phytoestrogens e.g. genistein (2).

\section{Mechanisms of action of EDs}

Given the complexity of endocrine system, the mechanisms of action of EDs are difficult to predict [16]. Many of the EDs are substances that act by interfering with the estrogen receptors (ER), androgen receptor (AR), thyroid receptors (TRs) and progesterone receptors, among others [2].

\section{Effect on estrogen, androgen and thyroid receptors}

Following binding to a receptor the EDs can trigger two types of responses: a hormonal response that is termed an agonistic effect, or a lack of hormonal response that is termed an antagonistic action. Agonistic effects of methoxychlor (MTX), an organochlorine pesticide used as an insecticide that was intended to replace DDT, have been reported for the estrogen receptor subtypes ER $\alpha$ and ER $\beta$, whereas an opposite response was noted for the androgen receptor $[17,18,19]$. A similar anti-androgenic effect has been noted for environmental polluting chemical 2,3,7,8-tetrachlorodibenzo-p-dioxin (TCDD) that has been shown to be an inhibitor or antagonist of hormone synthesis [20]. It is important to highlight that the EDs exhibit multiple hormone-binding activities irrespective of binding to hormonal receptors. For example, the DDT is an agonist for the estrogen receptor, whereas one of its metabolites is an anti-androgen [21]. BPA is a thyroid hormone antagonist in addition to its estrogenic and androgenic activity [22, 23]. BPA and other EDs interfere with thyroid hormone (TH) and thyroid hormone stimulating hormone (TSH) signalling via a majority of pathways that result in alteration of deiodinase activity, inhibition of TH excretion and/or metabolism, blockage of iodine uptake by thyroid cells, competitive inhibition of the thyroid transport protein TTR and antagonism of complexes that originate from the thyroid hormone responsive elements (TREs) [24,25]. The structural similarity of TH with specific TH-EDs, namely brominated flame retardants, hydroxylated polychlo- 


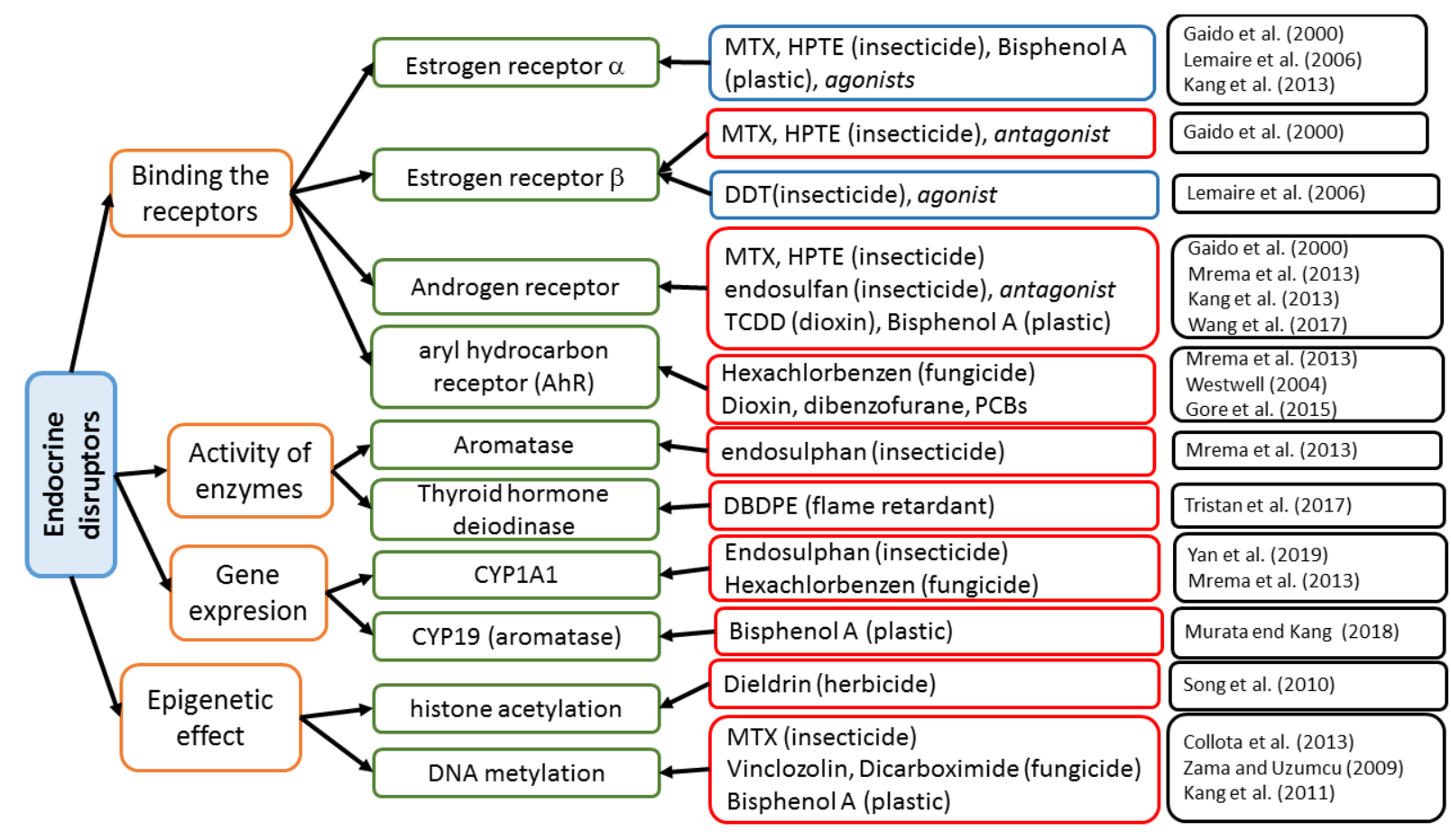

FIGURE 1 Endocrine disruptors and their mechanisms of action. DBDPE - decabromodiphenylethane, MTX - methoxychlor, HPTE - 2,2-bis(p-hydroxyphenyl)-1,1,1-trichloroethane, TCDD - 2,3,7,8-tetrachlorodibenzo-p-dioxin, DDT - dichlorodiphenyltrichloroethane and metabolite

rinated biphenyls (PCB) metabolites, and dioxins (PCDD) results in binding the $\mathrm{TH}$ transport protein TTR with a high affinity and consequently in inhibition of T4-TTR binding $[26,27]$.

\section{Effect on aryl hydrocarbon receptor}

At the molecular level, the EDs can affect the expression of steroid and sex hormone related enzymes by inducing their corresponding transcription, via binding to nuclear receptors. Notably organochlorine pesticides and dioxins have been documented to bind with considerable potency to the aryl hydrocarbon receptor (AhR) that induces the expression of CYP1 gene that in turn metabolizes estradiol (E2) to hydroxylated derivatives [28, 29]. The AhR is present in cytoplasm and binds with at least three proteins (chaperon protein HSP90, regulatory protein P23 and immunophilin-like protein XAP20). These proteins keep AhR in a state responsive to ligand binding. In the absence of ligand, AhR is bound to heat shock protein Hsp90. Regulatory proteins are displaced when ligand binding occurs, and the AhR enters the nucleus where it complexes and heterodimerizes with its nuclear partner hydrocarbon receptor nuclear translocator (Arnt) [30]. Heterodimer, which is formed, acquires the ability to bind specific DNA enhancer sequences known as xenobiotic responsive element (XRE), causing induction of enzyme, enhancing metabolism of endogenous hormone [31, 32]. Generally, products of these genes belong to one or two broad categories, drug-metabolizing enzymes and growth-regula- tory proteins. The most studied AhR-target genes are cytochrome P450 1A1, CYP 1A1, CYP1A2, and CYP1B1, and oncogenes [33].

\section{Effect on hormone synthesis and metabolism}

Some EDs are also capable of modifying hormone bioavailability by interfering with its secretion and transport or disrupting the enzymatic pathways involved in hormone synthesis and metabolism [34, 35]. For instance, in either sex, androgens give rise to oestrogens through aromatase, so together they play a vital role in homeostasis [36]. Those EDs that interfere with aromatase (BPA and atrazine) stimulate its activity [37, 38, 39], while DDT and phthalates inhibit it [34, 40]. Recently, many virilising EDs (e.g. phthalates and BPA) have been found to be powerful cyclooxygenase inhibitors, reducing prostaglandin synthesis, and this might be the foremost mechanism by which they exert their effects [41].

\section{Effect on epigenetic mechanisms}

Some EDs, e.g. diethylstilbestrol (DES) and methoxychlor (MTX), can also have epigenetic effects; they can cause changes in gene function in the absence of DNA sequence alterations. Notably, epigenetic effects are mediated by transcription factors that repress or enhance the transcription of specific genes. The main mechanisms include DNA methylation, posttranslational modifications of histone proteins (acetylation and deacetylation) and non-coding RNA [42, 43, 44]. DNA methylation leads to a reduction of gene expression, since it affects binding 
of transcription factors to the DNA [45]. Posttranslational modifications of the histone proteins at specific amino acid residues, such as lysine, may alter the structure and function of chromatin [46]. It has been accepted that acetylation of histones results in the activation of transcription because of the relaxation of chromatin, whereas deacetylation results in the silencing of genes and transcriptional repression. Non-coding RNAs are transcripts of sequences that do not encode proteins but regulate the expression of genes in the cis and trans manner. They are involved in specific functions such as X-chromosome inactivation, genomic imprinting and developmental patterning and differentiation [47]. The DES can activate expression of immediate early genes in neonatal development such as c-fos, c-jun, c-myc and lactoferrin that are upregulated in childhood [48]. This effect was accompanied by hypomethylation of the promoter region of the lactoferrin gene in adult uterus [49], whereas when the animals were exposed to the same interval during adulthood, such pattern of methylation was not observed [50]. Organochlorine pesticide MTX causes epigenetic changes in the ovary. Hypermethylation in ER $\beta$ promoter sequence as an impact of MTX was described. The extent of DNA methylation in the promoter regions appears to be age-dependent. With regard to the gene targets that are methylated by MTX, genome-wide methylation analyses have indicated that majority of candidate genomic regions include transcription factors and ribosomal proteins [51].

\section{Conclusion}

This paper has reviewed the evidence regarding to EDs and their general characteristics, chemical nature and basic mechanisms of action. Endocrine disruption is a serious public problem that must not be ignored. It is necessary to remove these substances from the environment; for instance replace plastics by glass, reduce consumption of fatty animal products and prefer pesticides free food. Further research is necessary to improve knowledge about known EDs and their metabolites, and to identify endocrine-disruptive potential of chemicals, those replacing current EDs before they are widely distributed.

\section{Ethical approval}

The conducted research is not related to either human or animal use.

\section{Acknowledgement}

This work was supported by the National Agency of Agriculture Sciences, NAZV, Project No. QJ1510138, CellFit COST Action CA16119, MŠMT INTER-COST LTC 18059, Ministry of Health of the Czech Republic No. NV-18-01-00544 and Ministry of Health of the Czech Republic - CZ - DRO (FNBr. 65269705).

\section{Corresponding author}

Eva Chmelíková, Ph.D., Department of Veterinary Sciences, Czech University of Life Sciences Prague, Faculty of Agrobiology, Food and Natural Resources, Kamýcká 129, 165 00, Czech Republic, e-mail: chmelikova@af.czu.cz.

\section{Conflict of interest statement}

The authors declare they have no conflict of interest.

\section{References}

1. Damstra T, Page SW, Herrman JL, Meredith T. Persistent organic pollutants: potential health effects? Journal of Epidemiology \& Community Health. 2002;56(11):824-5; DOI:10.1136/jech.56.11.824.

2. Diamanti-Kandarakis E, Bourguignon JP, Giudice LC, Hauser R, Prins GS, Soto AM, Zoeller RT, Gore AC. Endocrine-Disrupting Chemicals: An Endocrine Society Scientific Statement. Endocrine Reviews. 2009;30(4):293342; DOI:10.1210/er.2009-0002.

3. Kavlock RJ, Daston GP, DeRosa C, FennerCrisp P, Gray LE, Kaattari S, Lucier G, Luster M, Mac MJ, Maczka C, Miller R, Moore J, Rolland R, Scott G, Sheehan DM, Sinks T, Tilson HA. Research needs for the risk assessment of health and environmental effects of endocrine disruptors: A report of the US EPA-sponsored workshop. Environmental Health Perspectives. 1996;104:715-40; DOI:10.2307/3432708.

4. Brevini TAL, Cillo F, Antonini S, Gandolfi F. Effects of endocrine disrupters on the oocytes and embryos of farm animals. Reproduction in Domestic Animals. 2005;40(4):291-9; DOI:10.1111/j.1439-0531.2005.00592.x.

5. Calafat AM, Ye XY, Wong LY, Reidy JA, Needham LL. Exposure of the US population to bisphenol A and 4-tertiary-octylphenol: 2003-2004. Environmental Health Perspectives. 2008;116(1):39-44; DOI:10.1289/ ehp.10753.

6. Schiliro T, Gorrasi I, Longo A, Coluccia S, Gilli G. Endocrine disrupting activity in fruits and vegetables evaluated with the E-screen assay in relation to pesticide residues. Journal of Steroid Biochemistry and Molecular Biology. 2011;127(1-2):139-46; DOI:10.1016/j.jsbmb.2011.03.002.

7. Fingler S, Drevenkar V, Tkalcevic B, Smit Z. Levels of polychlorinated-biphenyls organochlorine pesticides, and and chlrophenols in the Kupa river water and in drinking waters from different areas of Croatia. Bulletin of Environmental Contamination and Toxicology. 1992;49(6):80512; DOI:10.1007/bf00203151.

8. Abbassy MS, Ibrahim HZ, Abu El-Amayem MM. Occurrence of pesticides and polychlorinated biphenyls in water of the Nile river at the estuaries of Rosetta and Damiatta branches, North of Delta, Egypt. Journal of Environmental Science and Health Part B-Pesticides Food Contaminants and Agricultural Wastes. 1999;34(2):255-67; DOI:10.1080/03601239909373196.

9. Rajapakse N, Silva E, Kortenkamp A. Combining xenoestrogens at levels below individual No-observed-effect concentrations dramatically enhances steroid hormone action. Environmental Health Perspectives. 2002;110(9):917-21; DOI:10.1289/ehp.02110917.

10. Silva E, Rajapakse N, Kortenkamp A. Something from "nothing" - Eight weak estrogenic chemicals combined at concentrations below NOECs produce significant mixture effects. Environmental Science \& Technology. 2002;36(8):1751-6; DOI:10.1021/es0101227.

11. Vom Saal FS, Hughes C. An extensive new literature concerning low-dose effects of bisphenol A shows the need for a new risk assessment. Environmental Health Perspectives. 2005;113(8):926-33; DOI:10.1289/ehp.7713; DOI: 10.1289/ehp.7713.

12. Vandenberg LN, Chahoud I, Heindel JJ, Padmanabhan V, Paumgartten FJR, Schoenfelder G. Urinary, Circulating, and Tissue Biomonitoring Studies Indicate Widespread Exposure to Bisphenol A. Ciencia \& Saude Coletiva. 2012;17(2):407-34; DOI:10.1590/s1413-81232012000200015.

13. Welshons WV, Thayer KA, Judy BM, Taylor JA, Curran EM, vomSaal FS. Large effects from small exposures. I. Mechanisms for endocrine-disrupting chemicals with estrogenic activity. Environmental Health Perspectives. 2003;111(8):994-1006; DOI:10.1289/ehp.5494.

14. Vandenberg LN, Colborn T, Hayes TB, Heindel JJ, Jacobs DR, Lee DH, Myers JP, Shioda T, Soto AM, vom Saal FS, Welshons WV, Zoeller RT. Regulatory decisions on endocrine disrupting chemicals should be based on the principles of endocrinology. Reproductive Toxicology. 2013;38:1-15; DOI:10.1016/j.reprotox.2013.02.002.

15. Boerjan ML, Freijnagel S, Rhind SM, Meijer GAL. The potential reproductive effects of exposure of domestic ruminants to endocrine disrupting compounds. Animal Science. 2002;74:3-12; WOS:000176332900002.

16. De Coster S, van Larebeke N. Endocrine-disrupting chemicals: associated disorders and mechanisms of action. Journal of Environmental and Public Health. 2012; 713696; DOI:10.1155/2012/713696.

17. Gaido KW, Maness SC, McDonnell DP, Dehal SS, Kupfer D, Safe S. Interaction of methoxychlor and related compounds with estrogen receptor alpha and beta, and androgen receptor: structure-activity studies Molecular Pharmacology. 2000;58(4):852-8; WOS:000089488700024. 
18. Lemaire G, Mnif W, Mauvais P, Balaguer P, Rahmani R. Activation of alphaand beta-estrogen receptors by persistent pesticides in reporter cell lines. Life Sciences. 2006;79(12):1160-9; DOI:10.1016/j.lfs.2006.03.02.

19. Mrema EJ, Rubino FM, Brambilla G, Moretto A, Tsatsakis AM, Colosio C Persistent organochlorinated pesticides and mechanisms of their toxicity. Toxicology. 2013;307:74-88; DOI:10.1016/j.tox.2012.11.015

20. Gore AC, Chappell VA, Fenton SE, Flaws JA, Nadal A, Prins GS, Toppari J, Zoeller RT. Executive Summary to EDC-2: The Endocrine Society's Second Scientific Statement on Endocrine-Disrupting Chemicals. Endocrine Reviews. 2015;36(6):593-602; DOI:10.1210/er.2015-1093.

21. Kelce WR, Stone CR, Laws SC, Gray LE, Kemppainen JA, Wilson EM. Persistent DDT metabolite P,P'-DDE is a potent androgen receptor antagonist. Nature. 1995;375(6532):581-5; DOI:10.1038/375581a0.

22. Wetherill YB, Fisher NL, Staubach A, Danielsen M, White RWD, Knudsen KE. Xenoestrogen action in prostate cancer: Pleiotropic effects dependent on androgen receptor status. Cancer Research. 2005;65(1):54-65 WOS:000226080200009.

23. Wang H, Ding Z, Shi QM, Ge X, Wang HX, Li MX, Chen G, Wang Q, Ju Q Zhang JP, Zhang MR, Xu LC. Anti-androgenic mechanisms of Bisphenol A involve androgen receptor signaling pathway. Toxicology. 2017;387:106; DOI:10.1016/j.tox.2017.06.007.

24. Hamers T, Kamstra JH, Cenijn PH, Pencikova K, Palkova L, Simeckova P, Vondracek J, Andersson PL, Stenberg M, Machala M. In Vitro Toxicity Profiling of Ultrapure Non-Dioxin-like Polychlorinated Biphenyl Congeners and Their Relative Toxic Contribution to PCB Mixtures in Humans. Toxicological Sciences. 2011;121(1):88-100; DOI:10.1093/toxsci/ kfr043.

25. Butt CM, Stapleton HM. Inhibition of Thyroid Hormone Sulfotransferase Activity by Brominated Flame Retardants and Halogenated Phenolics. Chemical Research in Toxicology. 2013;26(11):1692-702; DOI:10.1021/ tx $400342 \mathrm{k}$

26. Grimm FA, Lehmler HJ, He XR, Robertson LW, Duffel MW. Sulfated Metabolites of Polychlorinated Biphenyls Are High-Affinity Ligands for the Thyroid Hormone Transport Protein Transthyretin. Environmental Health Perspectives. 2013;121(6):657-62; DOI:10.1289/ehp.1206198.

27. Smythe TA, Butt CM, Stapleton HM, Pleskach K, Ratnayake G, Song CY, Riddell N, Konstantinov A, Tomy GT. Impacts of Unregulated Novel Brominated Flame Retardants on Human Liver Thyroid Deiodination and Sulfotransferation. Environmental Science \& Technology. 2017;51(12):7245-53; DOI:10.1021/acs.est.7b01143

28. Bradshaw TD, Trapani V, Vasselin DA, Westwell AD. The aryl hydrocarbon receptorin anticancerdrug discovery: Friend or foe? Current Pharmaceutical Design. 2002;8(27):2475-90; DOI:10.2174/1381612023392784.

29. Park WH, Kang S, Lee HK, Salihovic S, van Bavel B, Lind PM, Pak YK, Lind L. Relationships between serum-induced AhR bioactivity or mitochondrial inhibition and circulating polychlorinated biphenyls (PCBs). Scientific Reports. 2017;7; DOI:10.1038/s41598-017-09774-1.

30. Hoffman EC, Reyes H, Chu FF, Sander F, Conley LH, Brooks BA, Hankinson $\mathrm{O}$. Cloning of a factor required for activity of the Ah (dioxin) receptor. Science. 1991;252(5008):954-8; DOI:10.1126/science.1852076.

31. Dolwick KM, Swanson HI, Bradfield CA. In-vitroanalysis of Ah receptor domains involved in ligand-activated DNA recognition. Proceedings of the National Academy of Sciences of the United States of America. 1993;90(18):8566-70; DOI:10.1073/pnas.90.18.8566.

32. Sharma RP, Schuhmacher M, Kumar V. Review on crosstalk and common mechanisms of endocrine disruptors: Scaffolding to improve PBPK/PD model of EDC mixture. Environment International. 2017;99:1-14; D0I:10.1016/j.envint.2016.09.016.

33. Kawajiri K, Fujii-Kuriyama Y. Cytochrome P450 gene regulation and physiological functions mediated by the aryl hydrocarbon receptor. Archives of Biochemistry and Biophysics. 2007;464(2):207-12; DOI:10.1016/j.abb.2007.03.038

34. Whitehead SA, Rice S. Endocrine-disrupting chemicals as modulators of sex steroid synthesis. Best Practice \& Research Clinical Endocrinology \& Metabolism. 2006;20(1):45-61; DOI:10.1016/j.beem.2005.09.003.

35. Phillips KP, Foster WG, Leiss W, Sahni V, Karyakina N, Turner MC, Kacew S, Krewski D. Assessing and managing risks arising from exposure to endocrine-active chemicals. Journal of Toxicology and Environmental Health-Part B-Critical Reviews. 2008;11(3-4):351-72; DOI:10.1080/10937400701876657.

36. Basavarajappa MS, Craig ZR, Hernandez-Ochoa I, Paulose T, Leslie TC, Flaws JA. Methoxychlor reduces estradiol levels by altering steroidogenesis and metabolism in mouse antral follicles in vitro. Toxicology and Applied Pharmacology. 2011;253(3):161-9; DOI:10.1016/j. taap.2011.04.007.

37. Holloway AC, Anger DA, Crankshaw DJ, Wu M, Foster WG. Atrazine-induced changes in aromatase activity in estrogen sensitive target tissu- es. Journal of Applied Toxicology. 2008;28(3):260-70; DOI:10.1002/ jat.1275.

38. Arase S, Ishii K, Igarashi K, Aisaki K, Yoshio Y, Matsushima A, Shimohigashi Y, Arima K, Kanno J, Sugimura Y. Endocrine Disrupter Bisphenol A Increases In Situ Estrogen Production in the Mouse Urogenital Sinus. Biology of Reproduction. 2011;84(4):734-42; DOI:10.1095/ biolreprod.110.087502.

39. Murata M, Kang JH. Bisphenol A (BPA) and cell signaling pathways. Biotechnology Advances. 2018;36(1):311-27; DOI:10.1016/j biotechadv.2017.12.002.

40. Foster PMD. Mode of action: Impaired fetalLeydig cell function - Effects on male reproductive development produced by certain phthalate esters. Critical Reviews in Toxicology. 2005;35(8-9):713-9; DOI:10.1080/10408440591007395.

41. Kristensen DM, Skalkam ML, Audouze K, Lesne L, Desdoits-Lethimonier C, Frederiksen H, Brunak S, Skakkebæk NE, Jégou B, Hansen JB, Junker S, Leffers H. Many Putative Endocrine Disruptors Inhibit Prostaglandin Synthesis. Environmental Health Perspectives. 2011;119(4):534-41; DOI:10.1289/ehp.1002635.

42. Jirtle RL, Skinner MK. Environmental epigenomics and disease susceptibility. Nature Reviews Genetics. 2007;8(4):253-62; DOI:10.1038/ nrg2045.

43. Song C, Kanthasamy A, Anantharam V, Sun F, Kanthasamy AG. Environmental Neurotoxic Pesticide Increases Histone Acetylation to Promote Apoptosis in Dopaminergic Neuronal Cells: Relevance to Epigenetic Mechanisms of Neurodegeneration. Molecular Pharmacology. 2010;77(4):621-32; DOI:10.1124/mol.109.062174.

44. Kang ER, Iqbal K, Tran DA, Rivas GE, Singh P, Pfeifer GP, Szabó PE. Effects of endocrine disruptors on imprinted gene expression in the mouse embryo. Epigenetics. 2011;6(7):937-50.DOI:10.4161/epi.6.7.16067.

45. Collotta M, Bertazzi PA, Bollati V. Epigenetics and pesticides. Toxicology. 2013;307:35-41; DOI:10.1016/j.tox.2013.01.017.

46. Turner BM. Epigenetic responses to environmental change and their evolutionary implications. Philosophical Transactions of the Royal Society B-Biological Sciences. 2009;364(1534):3403-18; DOI:10.1098/ rstb.2009.0125.

47. Chang HS, Anway MD, Rekow SS, Skinner MK. RETRACTED: Transgenerational epigenetic imprinting of the male germline by endocrine disruptor exposure during gonadal sex determination (Retracted article. See vol. 150, pg. 2976, 2009). Endocrinology. 2006;147(12):5524-41; DOI:10.1210/en.2006-0987.

48. Nelson KG, Sakai Y, Eitzman B, Steed T, McLachlan J. Exposure to Diethylstilbestrol during a critical developmental period of the mouse reproductive-tract leads to persistent induction of 2 estrogen-regulated genes. Cell Growth \& Differentiation. 1994;5(6):595-606; WOS:A1994NP79900005.

49. Li SF, Washburn KA, Moore R, Uno T, Teng C, Newbold RR, McLachlan JA Negishi M. Developmental exposure to diethylstilbestrol elicits demethylation of estrogen-responsive lactoferrin gene in mouse uterus. Cancer Research. 1997;57(19):4356-9; WOS:A1997XZ01100036.

50. Li SF, Hansman R, Newbold R, Davis B, McLachlan JA, Barrett JC. Neonatal diethylstilbestrol exposure induces persistent elevation of c-fos expression and hypomethylation in its exon-4 in mouse uterus. Molecular Carcinogenesis. 2003;38(2):78-84; DOI:10.1002/mc.10147.

51. Zama AM, Uzumcu M. Fetal and Neonatal Exposure to the Endocrine Disruptor Methoxychlor Causes Epigenetic Alterations in Adult Ovarian Genes. Endocrinology. 2009;150(10):4681-91; DOI:10.1210/ en.2009-0499. 